\title{
Evaluating and negotiating a job offer
}

\author{
Norman Mortell, BA (Hons), RAnTech, MIAT \\ Knowing how to discuss salary and benefits is vital to receiving the best possible compensation package
}

The strongest position for negotiating remuneration and benefits is when you are first offered a job. It is also the time when you may know the least about your potential employer. To procure the best deal, I suggest making a checklist of your main vocational objectives and other key issues surrounding your potential job. Some general possibilities are listed below. No job will provide all or even most of these items, but considering the possible components of a compensation package will provide the framework for you to identify your priorities and determine how the job offer measures up to your expectations.

- Core package

- Base salary

- Salary structure

- Bonus/commission schemes

- Profit share

- Stock options/awards

- Equity share scheme

- Working hours, flexi time schemes

- Benefits

- Holiday entitlement and sick pay scheme

- Maternity/paternity leave arrangements

- Company car

- Relocation package

- Pension arrangements

- Private health/medical insurance

- Life insurance

- Mobile and home telephone

- Home security system

- Leisure/sports facilities

Norman Mortell is Director at the Hull-UK-based Agenda Resource Management, a company that specializes in recruitment. He is also Editor of $\mathrm{Lab}$ Animal Europe.Email: jobs@agenda-rm.co.uk. URL: http://www.agenda-rm.co.uk.
- Home computer or laptop with software

- Opportunities to attend conferences and seminars

- Continual professional development schemes

- Job title and scope

- Level of autonomy

- Opportunities for advancement

- Criteria for success

- Future plans

- Quality of the work environment

- Compatibility with your manager and colleagues

\section{Negotiating the package}

The actual negotiation is a sensitive issue and many people approach it with trepidation. I have found two keys to successfully navigating the pitfalls of salary and benefits discussions: appropriate timing and relevant knowledge.

Timing. Mentioning salary too early runs the risk of making you seem more interested in money than the job, but leaving the issue until after you have received a written offer may be too late. The type of job interview should largely determine when to broach the subject of salary. Remember, you are in your strongest position when they want you, but before they've got you.

During a first interview, wait until the end to ask for information about the salary range; however, this is not the time to start negotiating. During a second interview, the interviewer(s) will ideally provide the salary range up front; if not, ask for basic information, find out what the next stage is, and only start negotiating if and when they raise the subject. When you are sure that you are

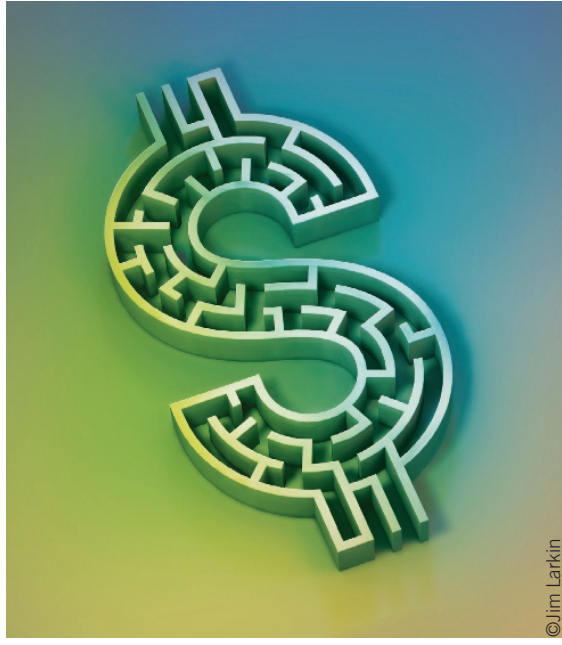

their first choice, begin negotiations. Do not hesitate if they propose to put the offer in writing.

Knowledge. You must know your financial needs and market value before you begin salary negotiations. Be prepared to support your salary proposal with relevant facts. Work out the total value of the package, before and after taxes, so you have figures for comparison with your current salary (and the industry averages if you can obtain them). Also find out how often salaries are reviewed and how increases are determined. Equally important, try to ascertain what the employer can afford and whether or not they are restricted by rigid salary structures and pay scales as this may limit your room for negotiation. Most of all, remember that money is not the 'end-all'; working for an organization that provides a stimulating and enjoyable working environment might be as important a determinant of job satisfaction as salary or benefits. 